\title{
A three phase photovoltaic grid tied inverter system control based on T-S Fuzzy equalization
}

\author{
Jameel Kaduim Abed \\ Electrical Technical Engineering College, Middle Technical University, Iraq
}

\begin{tabular}{|c|c|}
\hline Article Info & ABSTRACT \\
\hline Article history: & \multirow{10}{*}{$\begin{array}{l}\text { This paper proposed a Takagi-Sugeno fuzzy control method is used to build } \\
\text { the model for current controlled of three phase photovoltaic inverter. The } \\
\text { three phase inverter connected to grid with L filter. The DC link capacitor is } \\
\text { splatted midpoint of three phase four wire and the DC link voltage in the } \\
\text { input side of the inverter is considered as input variables value for maximum } \\
\text { value of the reference current for the feedback controlled. The proposed of T- } \\
\text { S fuzzy control method and hysteresis current control can solve and enhance } \\
\text { the THD of the output current of the inverter. The T-S fuzzy is designed to } \\
\text { monochrome controller makes the output currents are balanced and decrease } \\
\text { the harmonic compensation of the full system. The Matlab simulations and } \\
\text { test results show the THD, current and the voltage of the three photovoltaic } \\
\text { inverter under T-S fuzzy controller method is current balancing efficiency. } \\
\text { The control unit is capable of carrying out operation in good condition, } \\
\text { dynamic characteristics stable and high quality. }\end{array}$} \\
\hline Received Dec 11, 2018 & \\
\hline Revised Feb 19, 2019 & \\
\hline Accepted Mar 3, 2019 & \\
\hline Keywords: & \\
\hline Hysteresis current control & \\
\hline Photovoltaic & \\
\hline THD & \\
\hline Three phase inverter & \\
\hline & \\
\hline
\end{tabular}

Copyright (C) 2019 Institute of Advanced Engineering and Science. All rights reserved.

\section{Corresponding Author:}

Jameel Kadhim Abed

Electrical Technical Engineering College,

Middle Technical University, Baghdad, Iraq.

Email: drjameel55@yahoo.com

\section{INTRODUCTION}

As the demand for electricity increases and people become more aware of environmental protection, the development of renewable energy and the use of distributed power generation, wind power generation and photovoltaic power generation have achieved unprecedented development. The power electronics technology and instrument in the world has expanded, the application of power electronic devices has penetrated into every corner of people's work and life. Inverters (single and three phase) as the heart of power electronic devices have also become the focus of application and research.

The three phase topology is the main part of many power electronic systems, including DC/AC and $\mathrm{AC} / \mathrm{DC}$ application systems. Also the three phase inverters for photovoltaic energy applications connected to the low and medium voltage grids. The three phase photovoltaic inverters are classified into current control inverter (CCI) and voltage control inverter (VCI). In this paper has been used the current control inverter. The current source inverter is widely used in three phase photovoltaic grid tie inverter because of its good control performance. Hysteresis current control is widely used in three phase photovoltaic inverter because of its fast current response and better stability. However, hysteresis current control is a powerful nonlinear theory, and the control of the switching element of the inverter is an equivalent. The current deceleration control is widely used in three-phase photovoltaic inverter due to the fast current response and better stability. However, the deceleration is a strong non-linear correlation, and is similar to the switch control.

Figure 1 shows the proposed system of a three phase photovoltaic inverter system. The simulation circuit of the system in this paper were perform by using MATLAB/Simulink software program. The aim of this paper is to calculate, simulate and implement new current control technique for three phase photovoltaic inverter connected to grid. In this paper, three phase four wire photovoltaic inverter based on the T-S fuzzy 
control method was used to solve the problem of controlling the feedback control of a the hysteresis loop current. The T-S fuzzy control method is one of the powerful theories, this theory is suitable for the control of nonlinear with time-varying. The control is a rule-based control, which directly adopts based control rules. The rest of the paper is organized as follows: section 2 presents the mathematical model of three phase inverter, section 3 presents the T-S fuzzy and hysteresis mathematical model, section 4 discusses the simulation results of full system, and finally, section 5 shows conclusions.

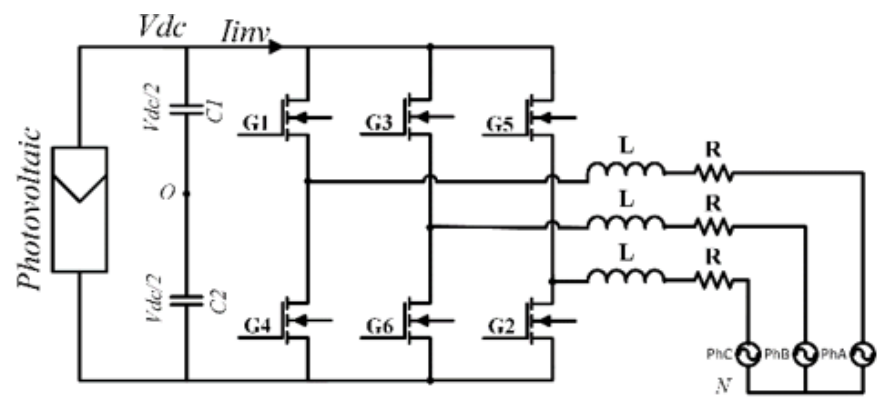

Figure 1. Three-phase four-wire inverter system

\section{MATHEMATICAL MODEL OF THREE PHASE INVERTER}

The mathematical model of three phase bridge photovoltaic inverter in the Figure 1 is based on two set points as a reference voltage points. In the Figure 1, point $N$ presents the neutral point of the three-phase grid, and point $\mathrm{O}$ is the midpoint of the DC side link capacitor voltage is divided into two. Shown in (1) present the set of the three phase inverter switching function Si to characterize the turn ON/OFF transistors.

$$
S_{i}= \begin{cases}1 & 1,3,5 \text { on } \text { and } 4,6,2 \text { off } \\ 0 & 1,3,5 \text { off } \text { and } 4,6,2 \text { on }\end{cases}
$$

Assuming that the output of the three phase inverter connected to inductance and resistance, the mathematical model of the output is established based on Figure 1 is as shown in (2) [4].

$$
\begin{aligned}
& R_{a c} i_{a}+L_{a c} \frac{d i_{a}}{d t}=V_{G a}-S_{p h a} V_{d c}-v_{O N} \\
& R_{a c} i_{b}+L_{a c} \frac{d i_{b}}{d t}=V_{G b}-S_{p h b} V_{d c}-v_{O N} \\
& R_{a c} i_{b}+L_{a c} \frac{d i_{b}}{d t}=V_{G b}-S_{p h b} V_{d c}-v_{O N} \\
& R_{a c} i_{b}+L_{a c} \frac{d i_{b}}{d t}=V_{G b}-S_{p h b} V_{d c}-v_{O N}
\end{aligned}
$$

Where, VGa, VGb, and VGc Represent phase voltage of three phase three wire grid. The phase voltage of each phase of the grid relative to the midpoint N. Vpha, Vphb, and Vphc present the output voltage of the inverter.

\section{T-S FUZZY AND HYSTERESIS MATHEMATICAL MODEL}

From the Figure 1, the main analysis of the circuit of three-phase four-wire, the voltage in the DC side is spilt into two equal voltage across the same value of capacitors $(\mathrm{C} 1=\mathrm{C} 2)$ Compared with the threephase three-wire. If we using traditional control theory methods, then the linear systems is very complexity of control. The method of T-S fuzzy control is used in this work to be simplified the full control system.

The hysteresis control of three phase photovoltaic inverter is a strong nonlinear control technique. The T-S fuzzy console features perfect dynamic performance, is not sensitive to changes in the process 
parameters of the system, and has strong durability. Therefore, the controller is designed to include a T-S fuzzy algorithm. The need for compensatory power changes the display of the hinge loop to achieve better compensation.

Figure 2 is the diagram of the controller system with the T-S fuzzy variable loop. According to the analysis of the hysteresis current control principle, the T-S fuzzy input variable is selected as the reference current. The deviation $(x(\Delta \mathrm{i}))$ from the actual current and its rate of change $\left(\mathrm{x}^{\prime}(\mathrm{d} \Delta \mathrm{i} / \mathrm{dt})\right)$, select the hysteresis loop width as the output variable (v) the fuzzy input amountx, $x^{\prime}$ is defined as in (3) and (4).

$$
\begin{aligned}
& x(t)=i^{*}(t)-i(t) \\
& x^{\prime}(t)=i(t)-i(t-1)
\end{aligned}
$$

Where, $x(t)$ and $x^{\prime}(t)$ are the command current and the actual current at time $t$ respectively and The scales of $x(t)$ is $x_{1}, x_{2}, x_{3}$ of $x^{\prime}$.

The maximum values of the $\mathrm{x}(\mathrm{t})$ and $\mathrm{x}^{\prime}(\mathrm{t})$ is considering that the value of the input variable exceeds the maximum value. In the case of the encirclement, the membership function of the $x(t)$ and $x^{\prime}(t)$ input variable is shown in Figure 3.

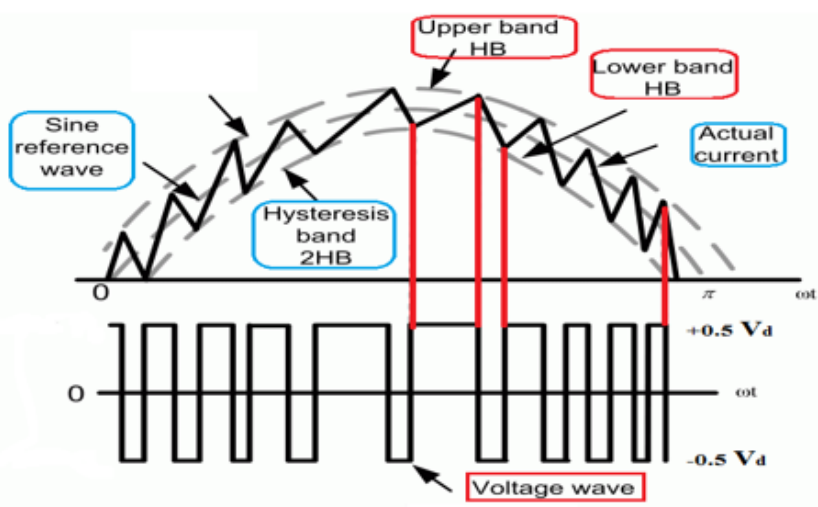

Figure 2. Hysteresis current control type

The four variables of the T-S fuzzy method are: ZE (zero), PS (positive), PM (median), PB (positive), $\mathrm{x}, \mathrm{x}^{\prime}$ and we use overlapping triangle membership functions. According to harmonics compensation current control requirements, can be found that the basic law of hysteresis loop width adjustment is: when e is larger, increase the loop width; when e is small, adjust the hysteresis loop width according to $\mathrm{x}^{\prime}$ when designing the T-S fuzzy controller, consider the impact of T-S fuzzy rule complexity on the timeliness. The corresponding T-S fuzzy control rules are shown in the Table 1.

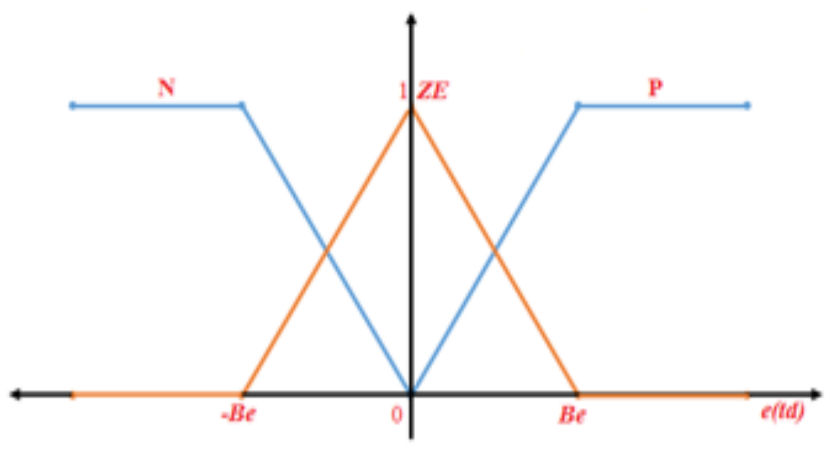

Figure 3. Fuzzy changing in error

Int J Pow Elec \& Dri Syst, Vol. 10, No. 2, June 2019 : 928-934 


\section{T-SIMULATION AND ANALYSIS RESULTS}

From the analysis in the previous paragraph, the DC voltages of the two capacitors on the DC link side are respectively sampled, and according to the T-S fuzzy controller. The final system of three-phase four-wire inverter with two capacitor voltage and T-S fuzzy control technique is shown in Figure 4 The simulation parameter of the full system is presented in the Table 2.

Table 1. The Fuzzy Parameter Rules

\begin{tabular}{ccccc}
\hline$x^{\prime}$ & & & $x$ & \\
& ZE & PS & PM & PB \\
\hline ZE & ZE & PS & PM & PB \\
PS & PS & PS & PM & PB \\
PM & PS & PM & PB & PB \\
PB & PM & PM & PB & PB \\
\hline
\end{tabular}

Table 2. The System Parameter

\begin{tabular}{cc}
\hline Parameter & value \\
\hline The inductor & $3 \mathrm{mH}$ \\
The resistance & $20 \Omega$ \\
The DC link capacitor C1 and C2 & $1000 \mathrm{uF}$ \\
DC link voltage & $500 \mathrm{~V}$ \\
Grid Phase & $230 \mathrm{~V}$ \\
\hline
\end{tabular}

Figure 5 to Figure 9 presents the simulation results of the full system is shows the three phase photovoltaic inverter model and the designee of the T-S fuzzy controller. The six PWM signals of the final three phase photovoltaic inverter is presented in the Figure 5. Figure 6 shows the two voltages of the DC Link side arose the two capacitor. The voltage of the DC link side with split capacitor is controlled and has good dynamic performance. According to the T-S fuzzy control method and hysteresis current control, the waveform of the output voltage of the three-phase inverter before filter is shown in Figure 7.

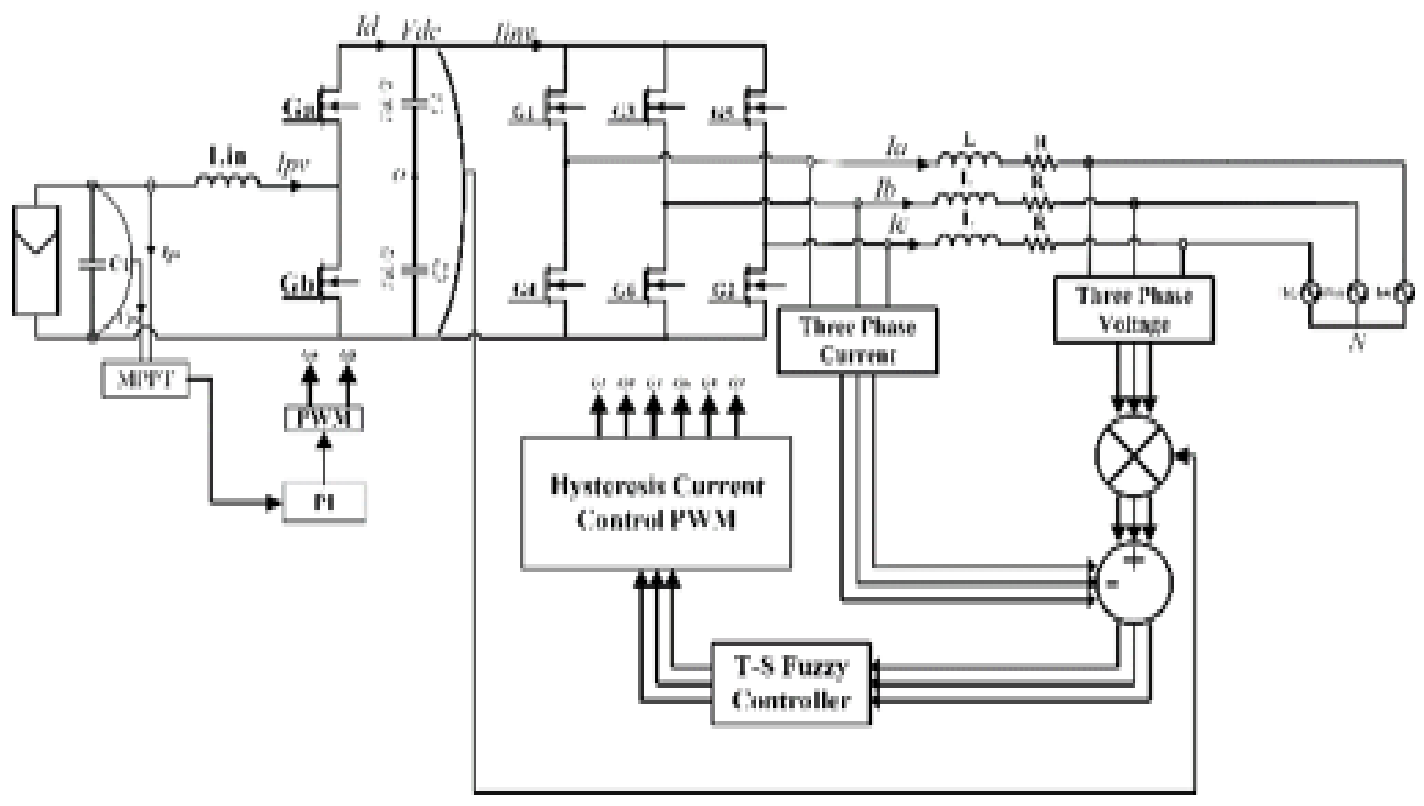

Figure 4. Full system of three phase photovoltaic inverter tied to grid with T-S fuzzy control method and hysteresis current control

Figure 8 present the three phase output voltage and current of the inverter after filter and before the grid connection. The performance of the three phase inverter four-wire, in the terms of harmonics elimination compensation, based T-S fuzzy control method and hysteresis current control is very satisfactory. The average of the THD of the output currents for full system values is equals to $2.8033 \%$ obtained adhere to the IEEE standard of THD $\leq 5 \%$. The FFT output of the three phase currents is presents in the Figure 9 . Figure $9 \mathrm{a}$ present the $\mathrm{THD}=2.95 \%$ of the current of phase A, Figure $9 \mathrm{~b}$ present the $\mathrm{THD}=3.0 \%$ of the current of phase $\mathrm{B}$ and finally Figure $9 \mathrm{c}$ present the $\mathrm{THD}=2.45 \%$ of the current of phase $\mathrm{C}$. 


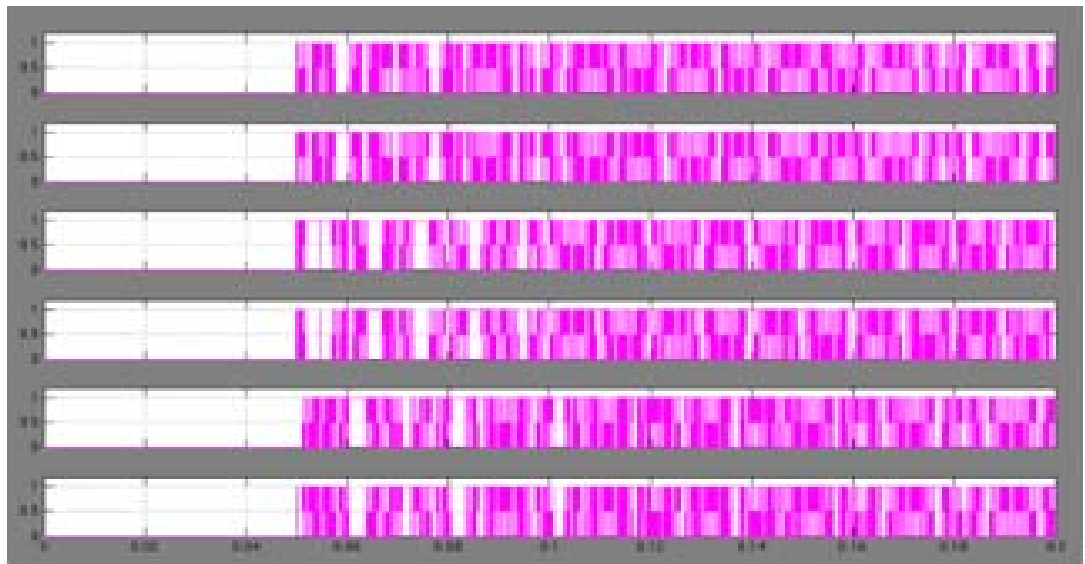

Figure 5. Six switches PWM of three phase inverter

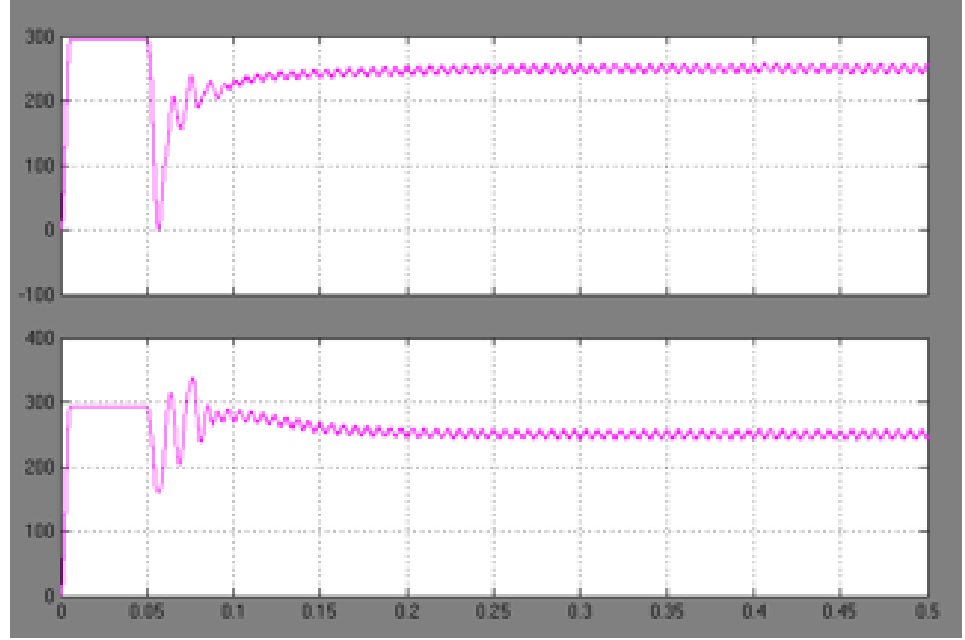

Figure 6. Upper and lower DC link capacitor voltages (C1 \& C2)

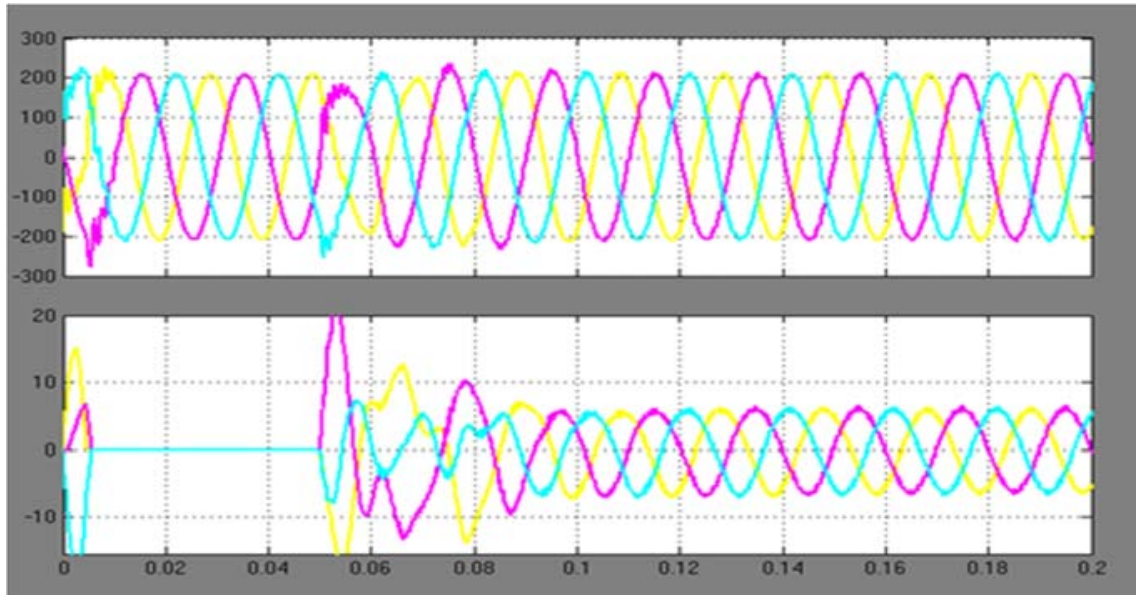

Figure 8. Three phase inverter output voltage and current (after filter) 


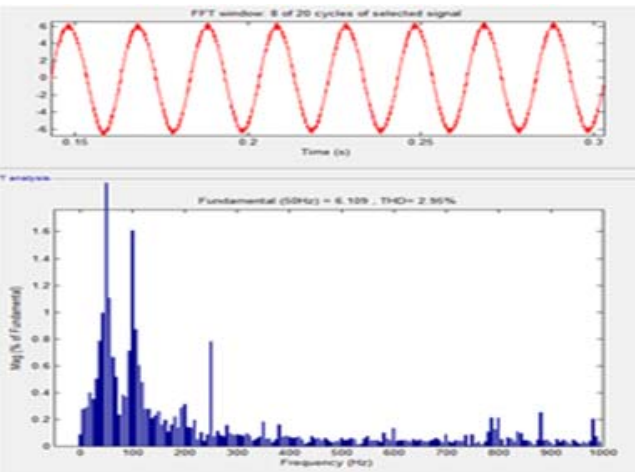

(a)

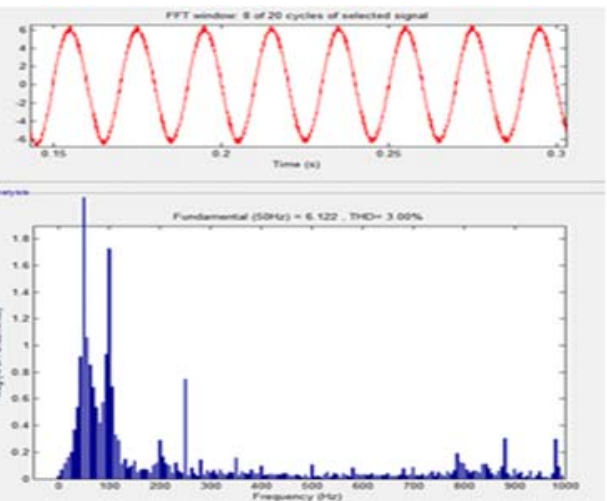

(b)

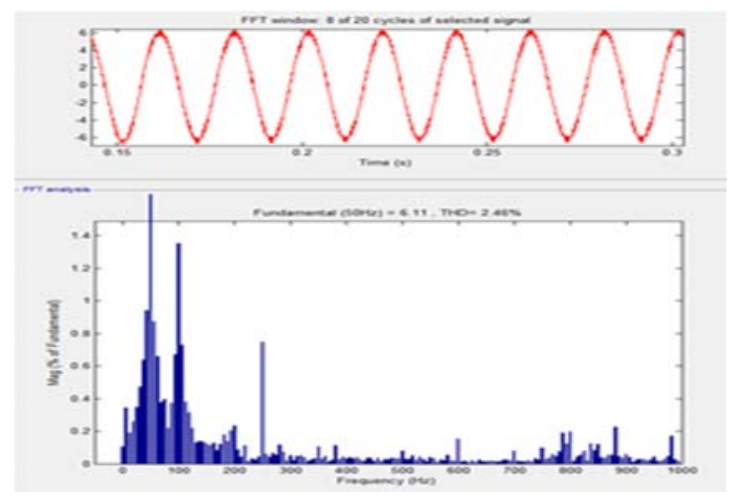

(c)

Figure 9. THD of the Three phase inverter output current (a) THD of the phase A oputput current, (b) THD of the phase B oputput current and (c) THD of the phase Coputput current

\section{CONCLUSION}

In this paper, the T-S fuzzy control method and hysteresis current control is used as a feedback control method with midpoint of the capacitor. Three-phase four-wire system is modelled with two sets of capacitors on the DC side As a control input, it effectively solves the voltage equalization of the midpoint of the capacitor splitting control problems while gaining real-time reference compensation current and power supply Flow implementation of feedback tracking control to compensate harmonics in power systems in real time Current and reactive power are compensated while compensating for current harmonics of each phase Harmonic current on the neutral line. Simulation results show that the method it is possible to split the capacitor at the midpoint of the three-phase four-wire for achieving DC side voltage Effective control of the reference compensation current through feedback control Real-time detection, continuous control output, high steady-state accuracy, and good motion.

\section{REFERENCES}

[1] W. Zheng, H. Wang, H. Wang, S. Wen, and Z. M. Zhang, "Fuzzy dynamic output feedback control for T-S fuzzy discrete-time systems with multiple time-varying delays and unmatched disturbances," IEEE Access, vol. 6, pp. 31037-31049, 2018.

[2] N. Farah, M. H. N. Talib, Z. Ibrahim, M. I. S. N, and J. M. Lazi, "Variable Hysteresis Current Controller with Fuzzy Logic Controller Based Induction Motor Drives," IEEE, no. October, pp. 2-3, 2017.

[3] A. Awasthi and D. Patel, "Implementation of adaptive hysteresis current control technique for shunt active power conditioner and its comparison with conventional hysteresis current control technique," 2017 IEEE Int. Conf. Signal Process. Informatics, Commun. Energy Syst. SPICES 2017, pp. 4-9, 2017.

[4] J. Sandeep, S. Ashok, and R. Ramchand, "Online Computation of Error Band for Hysteresis Current Controlled Reactive Current Compensators," 2016. 
[5] M. H. Zare, M. Mohamadian, and R. Beiranvand, "A Single-Phase Grid-Connected Photovoltaic Inverter Based on a Three-Switch Three-Port Flyback with Series Power Decoupling Circuit," IEEE Trans. Ind. Electron., vol. 64, no. 3, pp. 2062-2071, 2017.

[6] X. Liu and B. Liu, "Recognition of power quality disturbances based on T-S fuzzy logic," Proc. - 5th Int. Conf. Instrum. Meas. Comput. Commun. Control. IMCCC 2015, no. 1, pp. 302-305, 2016.

[7] L. Xiaoshen, Y. Xuehai, J. Mingzuo, and Z. Chunling, "Fuzzy inference modeling method based on T-S fuzzy system," J. Intell. Fuzzy Syst., vol. 31, no. 2, pp. 727-736, 2016.

[8] R. Nanjundaswamy, S. R. Angadi, N. R. Srinivas, and K. U. Vinayaka, "A vector control based shunt current compensation scheme for power quality improvement in high power radiology applications," Proc. 2015 IEEE Int. Conf. Power Adv. Control Eng. ICPACE 2015, pp. 48-52, 2015.

[9] Y. Wang, H. Chen, W. Wang, and T. Xiao, "Adaptive control for a class of nonlinear systems via T-S fuzzy logic systems with nonlinear rule consequents," Proc. 2015 27th Chinese Control Decis. Conf. CCDC 2015, pp. 376$381,2015$.

[10] T. Messo, J. Jokipii, J. Puukko, and T. Suntio, "Determining the value of DC-link capacitance to ensure stable operation of a three-phase photovoltaic inverter," IEEE Trans. Power Electron., vol. 29, no. 2, pp. 665-673, 2014.

[11] Y. Wang and F. Wang, "06341850.Pdf,” vol. 28, no. 6, pp. 2856-2866, 2013.

[12] M. Borrega, L. Marroyo, R. Gonźalez, J. Balda, and J. L. Agorreta, "Modeling and control of a master-slave PV inverter with n-paralleled inverters and three-phase three-limb inductors," IEEE Trans. Power Electron., vol. 28, no. 6, pp. 2842-2855, 2013.

[13] Mehrdad Ahmadi Kamarposhti, "Power Quality Compensation in Distribution System based on Instantaneous Power Theory and Recursive Fuzzy Proportional-Integral Controller," International Journal of Electrical and Computer Engineering (IJECE), vol. 8, no. 1, pp. 538-543, 2018.

[14] Q. Gao, G. Feng, Y. Wang, and J. Qiu, "Universal fuzzy controllers based on generalized T-S fuzzy models," Fuzzy Sets Syst., vol. 201, pp. 55-70, 2012.

[15] R. S. Ravi Sankar, S. V. J. Kumar, and G. M. Rao, "Adaptive Fuzzy PI Current Control of Grid Interact PV Inverter," International Journal of Electrical and Computer Engineering (IJECE), vol. 8, no. 1, p. 472, 2018.

[16] M. Castilla, J. Miret, A. Camacho, J. Matas, and L. G. De Vicuna, "Reduction of current harmonic distortion in three-phase grid-connected photovoltaic inverters via resonant current control," IEEE Trans. Ind. Electron., vol. 60, no. 4, pp. 1464-1472, 2013.

[17] M. J. Mnati, J. K. Abed, D. V. Bozalakov and A. Van den Bossche, "Analytical and calculation DC-link capacitor of a three-phase grid-tied photovoltaic inverter," 2018 IEEE 12th International Conference on Compatibility, Power Electronics and Power Engineering (CPE-POWERENG 2018), Doha, 2018, pp. 1-6.

[18] doi: 10.1109/CPE.2018.8372489

[19] Mohannad Jabbar Mnati, Dimitar V. Bozalakov, and Alex Van den Bossche, "A New Synchronization Technique of a Three-Phase Grid Tied Inverter for Photovoltaic Applications," Mathematical Problems in Engineering, vol. 2018, Article ID 7852642, 13 pages, 2018. https://doi.org/10.1155/2018/7852642.

[20] Mohannad Jabbar Mnati, Dimitar V. Bozalakov, and Alex Van den Bossche, "New Pulse Width Modulation Technique to Reduce Losses for Three-Phase Photovoltaic Inverters," Active and Passive Electronic Components, vol. 2018, Article ID 4157614, 10 pages, 2018. https://doi.org/10.1155/2018/4157614.

[21] A. Kiswantono, O. Penangsang, and A. Soeprijanto, "Transient Power Quality Performance of Multi Photovoltaics using MPPT P and O / MPPT Fuzzy," TELKOMNIKA (Telecommunication Computing Electronics and Control) ,vol. 16, no. 6, pp. 2967-2979, 2018.

[22] D. V. Bozalakov, T. L. Vandoorn, B. Meersman, g. K. Papagiannis, A. I. Chrysochos, and 1. Vandevelde, "Damping-based droop control strategy allowing an increased penetration of renewable energy resources in lowvoltage grids," IEEE Trans. Power Deliv., vol. 31, no. 4, pp. 1447-1455, 2016.

[23] I. H. Shanono, N. Rul, H. Abdullah, and A. Muhammad, "Five-Level Single Source Voltage Converter Controlled Using Selective Harmonic Elimination," Indonesian Journal of Electrical Engineering and Computer Science, vol. 12, no. 3, pp. 924-932, 2018.

[24] D. Bozalakov, T. L. Vandoorn, B. Meersman, C. Demoulias, and L. Vandevelde, "Voltage dip mitigation capabilities of three-phase damping control strategy," Electr. Power Syst. Res., Vol. 121, PP. 192-199, 2015.

\section{BIOGRAPHIES OF AUTHOR}

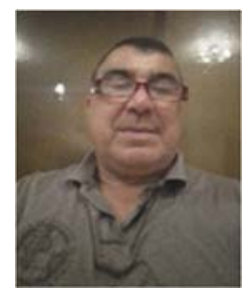

Jameel Kadhim Abed received his MSc and $\mathrm{PhD}$ degree in power system, machine and power electronics from the University of Baghdad in 1985 and 2003 respectively. He has worked at the Foundation of Military Production since 1988 as Head Master of the Development and Research Department in the field of power electronics (power supply and inverters). Currently he works in the Middle Technical University as Head Master of the Mechatronics Department and as lecturer in power electronics for undergraduate and postgraduate students as well as supervisor of master and high diploma students in the field of high frequency inverter and renewable energy. His research is on electrical drives and power electronics on various inverter types, and he is interested in renewable energy

Int J Pow Elec \& Dri Syst, Vol. 10, No. 2, June 2019 : 928-934 